\title{
ネットワーク算法による両眼立体視 の対応点決定方法
}

\author{
西 谷 卓 史*・舩 橋 誠 壽* \\ Stereo Matching Method Based on Network Algorithm \\ Takushi NishiyA* and Motohisa Funabashi*
}

In this paper we present a stereo matching method based on a network algorithm. The network to transport the characteristic features from one image to anothor is constructed as an electrical network connected by variable resistors. By this analogy the characteristic features can be considered as electrical current. Using this network, matching problem can be transformed as a computation of current distribution satisfying the constraints for the physical surface. In the step to find the distribution, we utilize the lateral inhibition theory and change iteratively the values of resistors.

Several algorithms were devised for stereo matching, such as a method using correlation coefficient, dynamic programming or the relaxation method. But these methods were not satisfactory because they need vast amount of calculation or they were not capable to obtain enough resolution.

In this paper, the method for detection of corresponding points by means of the network algorithm resolves the deficits of conventional methods. The method is able to use the images or those differences directly, furthermore, by the method a pixel of one image can be matched to any point between the pixels of the other image. Because of these facts, fine resolution can be obtained.

Experimental results are shown to confirm effectiveness of this method to navigate the locomotive vehicle. Although this method is defined on one dimensional, extension to two dimensional is easily performed by use of three dimensional network.

\section{* (株) 日立製作所システム開発研究所} 川崎市麻生区王禅寺 1099

* Systems Development Laboratory, Hitachi, Ltd., Kawasaki

(Received February 14, 1985)

(Revised September 2, 1985)
Key Words: stereo matching, network algorithm, lateral inhibitation

\section{1. まえがき}

近年, 各産業分野において, 人間に代わり保守・点 検作業を行う自律移動ロボットの要望が高まってい る1). このような自律機能をロボットに持たせるため には，ロボットの移動環境におかれた物体の位置や形 状を効率よく認識できるセンサシステムが必須となっ てくる. てのような移動ロボットの外界センサに要求 される特性としては, 適用できる環境や測定できる距 離の範囲が広いてと, さらに, 機構的に簡素であって センシング時間が移動速度に適合しているとと,など が挙げられる。

しかし, 従来開発されている移動ロボットの外界セ ンサは，人工的なマークを利用できる場合を除いて， 環境をかなり限定しなりればならず，実用とはほど遠 い状態にある2). 超音波は簡単な障害物の検出などに は用いられるが，分解能に問題がある. また,レー ザー光・ミリ波を用いる方法は, 発射方向の制御や, 伝幡時間の測定などに大型の装置が必要になる．視覚 を用いるものでは，スリット光やパターンの投影によ る三角測量を用いたすのが提案されているが, 照明の 明るい場所や遠方の物体への適用に難点がある. この ような問題点を克服するものとして, 受動的なセンシ ングを行う両眼立体視によるものが有望と考えられ る.

立体視による距離測定の試みは数多く発表されてい る. 立体視における最も重要な課題は, 左右眼から得 られる像から，同じ物体に対する像の対応関係を求め ることにある. この対応点決定の手法として種々の手 法が提案されている. 基本的な手法として, Marr ら の提案した Cooperative Algorithm ${ }^{3), 7), 8)}$ と呼ばれ ている弛緩法によるものやエッジの照合による方 
法7),8，10)，あるいは動的計画法によるあの42などがあ る.また，左右の像の間で相関の最む高い部分を対応 点とする相関法 ${ }^{5)}$ や各々の像から同じ特徵を持つ点を 発見して対応を取る特徵照合法 ${ }^{6}$ などが提案されてい る.

Cooperative Algorithm は random dot stereo の ように 2 值化された像に対して有効であるととが報告 されているが，濃淡情報を直接扱うことができないと いう問題点がある．また，エッジの照合による方法は 一種の特徵照合法であり, 各種の濃淡画像に有効であ るととが示されている. しかし，エッジの数により計 算時間が大幅に変化するといった問題点がある．動的 計画法によるものはエッジの強度も考慮できるため, 弛緩法を用いたものに較べあいまい性の少ない解が求 まるが，画素対画素の対応決定であるため精度が悪い という問題点がある. 相関法は，処理に非常に時間が かかる，あるいは，画面間で明るさや形状があまり 変化しない場合以外には適用できない，特徵照合法で は, 物体の認識に十分な特徵点の抽出が困難であると いう問題がある.

Marr らの cooperative algorithm は濃淡画像に $\nabla^{2} G$ フィルタを作用させ, 結果の符号を用いて 2 值 化した後で処理を行う. このため, エッジの強度など 特徵量を考慮できないという問題点があった．本論文 では, cooperative algorithm と同じ弛緩法にもと づき，しかもエッジの強度が考慮できる方法を報告す る! すなわち，対応点の決定とは，対となる一方の画 像から他方の画像へと物理的に矛盾なく特徵量を移し かえることであると考える．乙の移しかえのために， 特徵量を電流值と考えた抵抗回路網を考え，抵抗值の 更新のために，生体系の情報処理様式である側抑制理 論9)を用いた手法を提案する.

\section{2. ネットワーク算法 ${ }^{11) .12)}$ によるステレオ対応探索}

本章では，ステレオ対応探索にお ける拘束条件と，それを満足した対 応点決定を行うためのネットワーク の構成方法, 具体的な計算手順につ いて述べる.

\section{1 対応探索における拘束条件}

ステレオ対応探索においては，物 理的な表面のもつ単純な性質によ り，問題を十分に限定することがで きる7). その性質とは,

（1）Uniqueness: 物理的表面上の
ある一点は，どの時点においても，ただ一つの 3 次元配置しか持たない.

（2）Continuity：表面上での奥行きの変動は一般に 滑らかであり，しかも不連続的な変化は境界線 のところでしか生じない.

というととである.さらに Marr らは，2值化された 像においては，

（3）Compatibility：黒い点は黒い点としか対応し ない.

という拘束条件も導入し，以上三つの拘束条件を満足 する対応点は，実際の対応点と一致する，という仮説 を立てた

次節以下では，濃淡画像情報を用いて対応点を効率 的に求めるための，可変抵抗で接続された回路網を提 案する.さらに，乙の回路網上において前記拘束条件 を満足する電流分布を求める方法について述べる.

\section{2 ネットワークの構成}

本論文で扱うステレオ対は，左右の像は十分接近し た位置から撮影されており，両画像間の差は非常に小 さいとする．また，両画像は，左右の画像面が左右の カメラのレンズ中心を結ぶ線分 (base line) に平行に なる位置で撮影されており，視線投影線 (epipolar line）は画像の走査線に一致しているすのとする.

このような条件のもとでは，左右一対の走査線上で の対応探索を各走査線毎に独立に行えばよいととにな る. この探索を, 左右の走査線をそれぞれ横軸・縦軸 とする 2 次元の平面上で，対応づけを示すパスを探す 問題として考える.

Fig. 1 (a) に示すような抵抗回路網を考える. 縦 軸・横軸に右眼像と左眼像の一対の走査線上の各画素 を対応づけ，各画素から抵抗回路網に電流を流す電圧

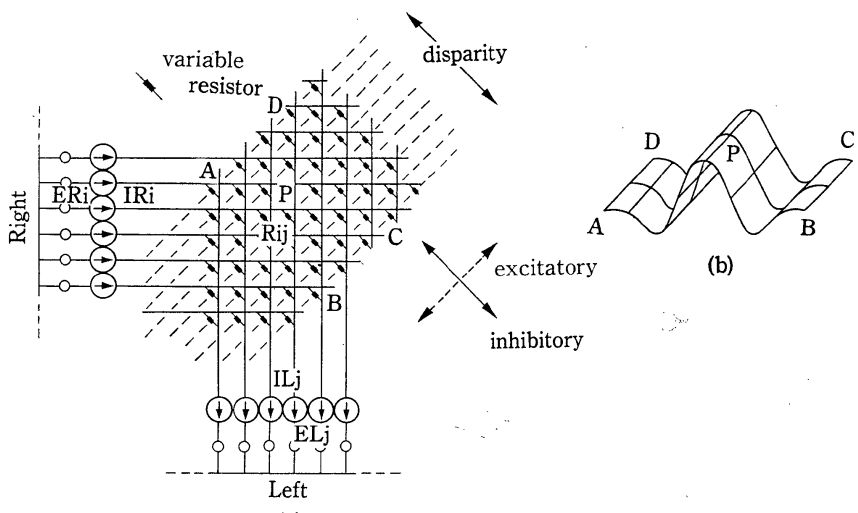

(a)

Fig. 1 (a) The structure of the network for stereo matching

(b) Pattern of weighting factor to change the value of variable resistors 
源 (ERi, ELj) を設定する. 左右の像の対応点を求め るととはこの電圧源と可変抵抗 $\left(R_{i j}\right)$ の值を調節する ことにより, 各画素の持つ特徵量に相当する電流值 $\left(I R_{i}, I L_{j}\right)$ を, 右眼の像から左眼の像へ之, 前節の 三つの拘束条件を満足させながら移しかえるときの電 流分布を求めればよいととになる.

\section{3 計算手順}

Fig. 1(a) のネットワーク上では次のオームの法則 が成立しなければならない。

$$
\left\{\begin{array}{l}
I R_{i}=\sum_{j=i-s}^{i+s} x_{i j} \quad(i=1,2, \cdots, m) \\
I L_{j}=\sum_{i=j-s}^{j+s} x_{i j} \quad(j=1,2, \cdots, m) \\
E R_{i}-E L_{j}=R_{i j} \cdot x_{i j} \\
\quad(i=1,2, \cdots, m ; j=1,2, \cdots, m)
\end{array}\right.
$$

乙てに, $x_{i j}$ は右眼像の $i$ 番目の画素から左眼像の $j$ 番目の画素へと流れる電流値である．また， $s$ は disparity 方向への回路網の広がりを示す定数である.

対応点の探索は，2.2 節の拘束条件と(1) 式を満足 する解を求めればよいととになる．とのような解は次 の計算手順 $(I I) 〜(I V)$ を数回繰り返すととにより求め られる。

（I） 各画素 $(i=1,2, \cdots, m ; j=1,2, \cdots, m)$ に対する 初期電位 $E R_{i}^{0}, E L_{j}^{0}$ および各可変抵抗の初期值 $R_{i j}^{0}$ を設定する.

（II） 各可変抵抗を流れる電流值 $x_{i j}(i=1,2, \cdots, m$; $j=1,2, \cdots, m)$ を

$$
x_{i j}^{t}=\left(E R_{j}^{t}-E L_{j}^{t}\right) / R_{i j}^{t}
$$

により求める.

（III） 各画素に対する電位 $E R_{i}(i=1,2, \cdots, m), E L_{j}$ $(j=1,2, \cdots, m)$ を

$$
\left\{\begin{array}{l}
E R_{i}^{t+1}=E R_{i}^{t}+\varepsilon\left\{I R_{i}-\sum_{j=i-s}^{i+s} x_{i j}^{t}\right\} \\
E L_{j}^{t+1}=E L_{j}^{t}-\varepsilon\left\{I L_{j}-\sum_{i=j-s}^{j+s} x_{i j}^{t}\right\}
\end{array}\right.
$$

により更新する.とこにとは適当な補正係数であ る.

（IV）各抵抗値を次式により更新し，ステップ(II)に 戻る.

$$
R_{i j}^{t+1}=R_{i j}^{t}-\beta \cdot \sum_{k, l} w(k, l) \cdot x_{k, l}
$$

ただし， $R_{i j}^{t+1}>10.0$ となる場合は $R_{i j}^{t+1}=10.0$ ， また $R_{i j}^{t+1}<1.0$ となる場合は $R_{i j}^{t+1}=1.0$ とおき かえる. (4) 式で, $w(k, l)$ は電流值 $x_{k, l}$ 亿対す る重み係数であり,てれについては後に詳述す る.また $\beta$ は適当な補正係数である.

以上の手順から電流分布が求められれば，対応点は
次式により求めるととができる.

$$
\begin{gathered}
\left\{\begin{array}{c}
d_{i}=\sum_{j=j_{m}-a}^{j_{m}+a}\left(j-j_{m}\right)\left|x_{i j}\right| / \sum_{j=j_{m}-a}^{j_{m}+a}\left|x_{i j}\right|+j_{m} \\
j_{m}=\left\{j ; \max \left|x_{i j}\right|, j=i-s, \cdots, i+s\right\} \quad(5)
\end{array}\right. \\
\text { ここに, } d_{i}: \text { 右眼像の } i \text { 番目の画素と対応する左 } \\
\text { 眼像の画素番号 } \\
s: \text { ネットワークの幅を示す定数 } \\
a: \text { 対応点を求める幅を示す定数 }
\end{gathered}
$$

(5)式は, 右眼像の $i$ 番目の画像之接続されている, ードから, 電流值が最大のあのを選び，このノードを 中心とする $\pm a$ の幅以内にあるノードの電流值に対 し，ノード間の距離を重みとして加重平均をすること を示している.

繰返し計算における (I)の初期值設定は次のように 行う. $E R_{i}$ 抽よび $E L_{j}$ は, 繰返し計算の終了時は $I R_{i}, I L_{j}$ 亿近い值となるため, $E R_{i}^{0}=I R_{i}, E L_{j}^{0}=$ $I L_{j}$ として与える. $R_{i j}^{0}$ は最も coarse な画像（これ については後に詳述する）に対する計算の開始時に は, $R_{i j}^{0}=5.0$ と与える. coarse to fine の過程での初 期值は，(5)式の計算結果を用い，

$$
R_{i j}^{0}=1.0+\left(j-d_{i}\right)^{2}
$$

ただし， $R_{i j}^{0}>10.0$ となる場合は $R_{i j}^{0}=10.0$ とし て与える. てれは対応点の存在する近傍から計算を開 始し, 収束に必要な計算回数を減らすためである.

収束の判定は, 電流值の変化あるいは対応点の変化 などのノルムを用いて行うことができる. しかし，て の計算屯かなりの量となるため, 種々の画像に対する 実験の結果から十分な繰返し回数之考えられる 20 回 の iteration で打ち切るととにする.

\section{4 抵抗值の更新方法}

本節では 2.1 節の拘束条件を満足させるための抵抗 值更新時の重みひについて詳述する.

Uniqueness および Continuity を満足させるため にFig. 1(b)に示すような重みづけを考える. この重 みづけは生体系における側㧕制の考え方に基づくあの である.すなわち，ある 1 点 $\mathrm{P} の$ 抵抗值を更新する には，Pの近傍の電流分布を考え，與奮性方向の抵抗 を流れる電流值には正の重みづけ，抑制性方向の抵抗 を流れる電流値には負の重みづけを行い，それらの総 和により更新する量を求める．乙れにより，抑制性方 向に大きな電流值を持つ抵抗があれば，P点の抵抗值 は增大し，興奮性方向に大きな電流值を持つ抵抗があ れば，抵抗值は減少し，益々電流值は大きくなってゆ く.

ての重みづけパターンにより各画素からの電流值は 複数の部分に分散するととがなく，唯一の画素近傍に 


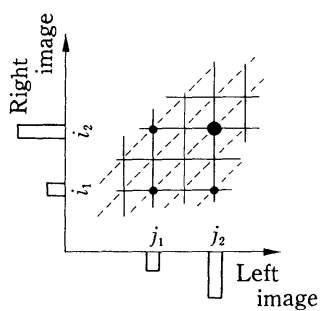

(a)

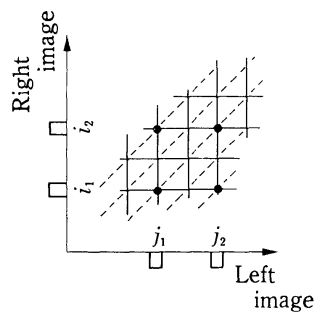

(b)

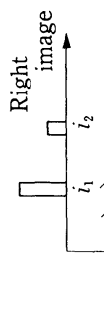

ある程度 occluding の検出も行 うことができる。一方, Marr らの方法ではFig. 2(a)上Fig. 2 (c)の差異が検出できないた め, Fig. 2(c)の場合において 屯 $i_{1}$ と $j_{1}, i_{2}$ と $j_{2}$ という愦っ た対応付けを行ってしまう。

\section{3. 計 算 例}

本章では，前章で述べた計算

Fig. 2 A comparison with a cooperative algorithm

(c)

(a) proposed method (b) cooperative algorithm (c) an example of false target

集中して流れ, Uniqueness を満足する解を得ること ができる，また，重みづけパターンを，興奮性の方向 に数画素の幅をあたせていることにより，大きい電流 值を持つ抵抗があれば, 興奮性方向の隣あった抵抗の 抵抗值を減少させ，同じ disparity の方向に電流值の 大きい抵抗が並ぶようになり, continuity を満足させ るととができる.

Compatibility は電位の考え方を導入することで満 足させることができる：すなわち，電位という概念を 導入することにより, 右眼像の大きい特徴量を持つ画 素は，電位が高く（正の極性を持つ特徽量の場合）な り, 対となる画像中の電位の低い（負の極性を持つ特 徵量の場合) 特徵量を持つ画素との間に大きな電流が 流れる.乙ういう強い流れは, 周囲の弱い特徵量に影響 されずに対応点が決定される. こういう強い特徴量の matching から順次に弱い特徵量へと対応づけされて ゆくために, Compatibility を満足する解が得られる. 以上のように電位と電流という概念を導入した効果 をFig. 2 を用いて具体的に説明する. Fig. 2 (a)に 示すような特徵量の分布があるとする. この場合, 収 束計算の開始時には, 図に示したように $i_{2}$ から $j_{2}$ へ の電流 $x_{i_{2} j_{2}}$ が大きくなる，計算を繰返すに従い, この $x_{i_{2 j 2}}$ が他の電流に側抑制の効果を及ぼし， $x_{i_{1 j 2}}$ および $x_{i 2 i_{1}}$ が抑制され， $x_{i_{1 j 1}}$ が興舊してゆく.乙 のように大きな電流值を持つ部分が側抑制において大 きな役割りをすることから収束性の向上とあいまい性 の減少という効果を得ることができる.

Marr らの提案した手法では, Fig. 2(b)に示すよ うに2 值化されたデータを扱うために, それぞれの 画素間の結合度が同等に評価されるため, 収束性が悪 く, あいまい性が残る. Fig. 2(c)のようにエッジ強 度の順序が入れ替わっている場合, 本論文の方法によ れば， $x_{i_{1 j 2}}$ が大きな電流值として残り， $i_{2}$ および $j_{2}$ が対応する画素は白丸で示す異なる画素に対応づけら れる. 電流值の大きい対応付けがない場合は occludingがあると考えることにより，本論文の方法では
方式を実画像に適用した例について述べる.

\section{1 走査線内探索}

Fig. 3 亿計算に用いた右眼像と左眼像を示す.乙 れらの像はレンズ中心が $10 \mathrm{~cm}$ 離れた位置から撮影さ れたものであり，縦横とあ512 画素からなる。また， 各画素は 8 bit (256 レベル) の濃淡情報をあつ。

この画像に対し, 最初から1画素単位の計算を行っ てゆくのは, 枝数（1 つの画素から対となる画像に張 る枝数 $2 s+1)$ が非常に多いネットワークを扱う必 要が生ずるばかりでなく，䛊った対応結果の点も多く なってしまう.このため, ここでは coarse to fine strategy ${ }^{5,10)}$ を用いている。しかし，乙れでは䛊った 対応結果は减少するが, 大きいネットワークを最初か ら扱わねばならない欠点が残る。そこで, coarse to fine の過程では領域毎の平均明るさを用いた計算を, 大きい領域を用いたものから，小さい領域を用いたも のへと順次繰返すととにする.

Fig. 4 亿原画像の下加第 338 番目の走査線の データを示す. Fig. 4(a) は右眼像, Fig. 4(b) は左 眼像である. この走査線に対する対応点の計算結果を Fig. 5 亿示す。横軸は右眼像の画素番号であり, 緹 軸は各画素が対応する左眼像の位置とのずれ量（画素 数）を右方向へのずれを正として表示している。 ま た，ここでは下式に示す微分を行った結果を特徴量 $I R_{i}, I L_{j}$ として与えている.

$$
\left\{\begin{array}{l}
I R_{i}=B R_{i+1}-B R_{i-1} \\
I L_{j}=B L_{j+1}-B L_{j-1}
\end{array}\right.
$$

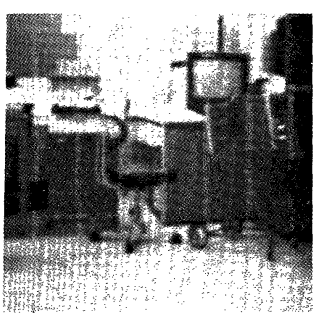

(a) left image

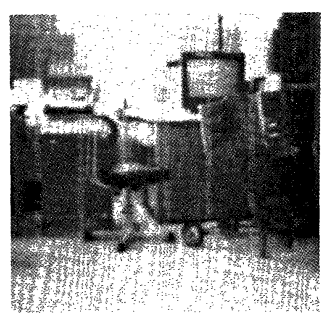

(b) right image
Fig. 3 An example of stereo images 


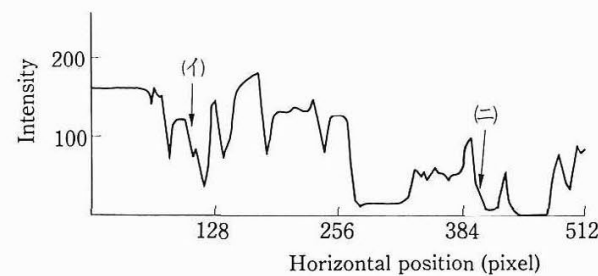

(a) right image

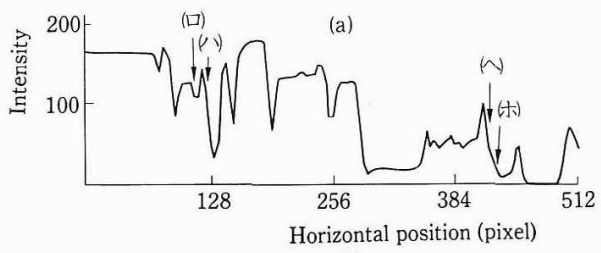

(b)

Fig. 4 Intensity change for the scanline 338

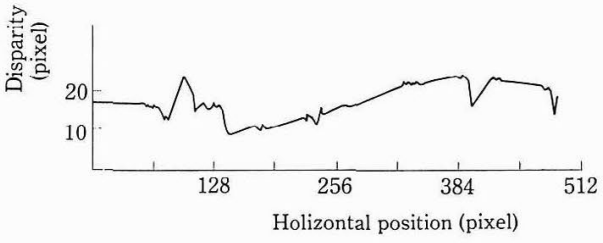

Fig. 5 The result of applying the algorithm for the scanline

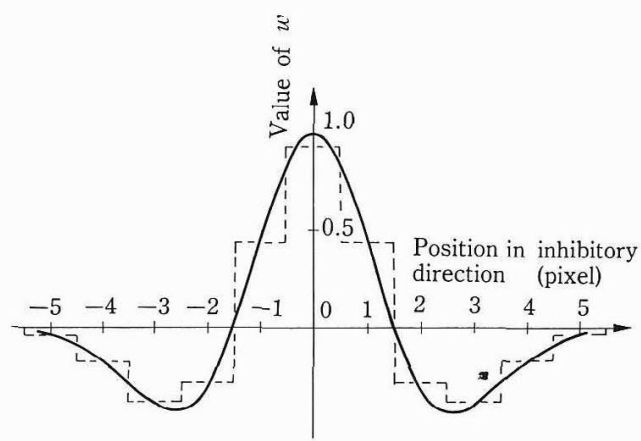

Fig. 6 Applied cross sectional pattern of weighting factr $w$

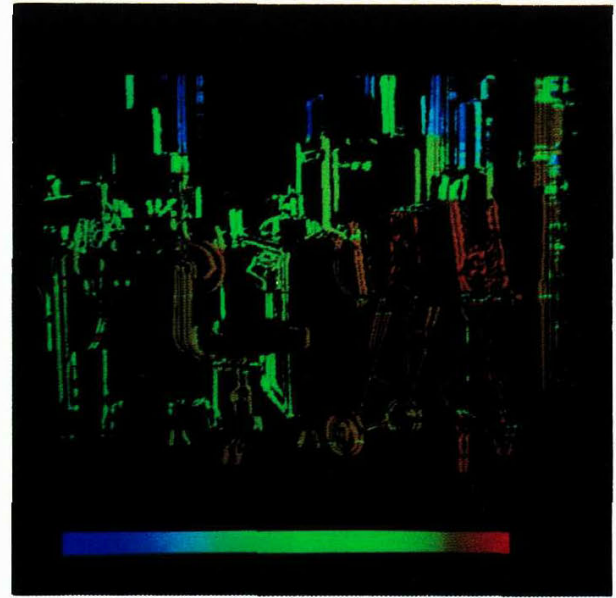

Fig. 7 The result for whole image, inconsidering the consistency across scanlines

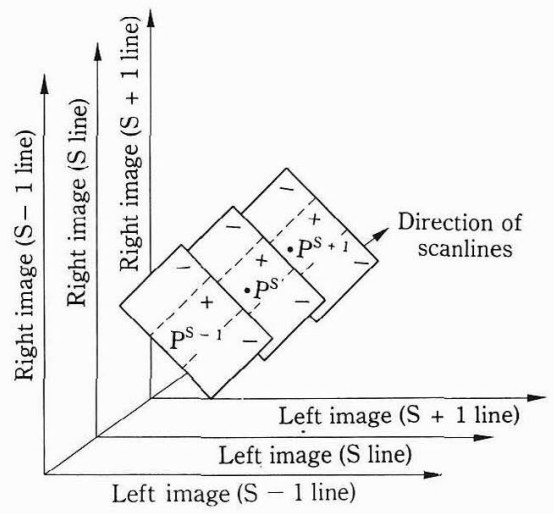

Fig. 8 The illustration of the method to consider the consistency across scanlines

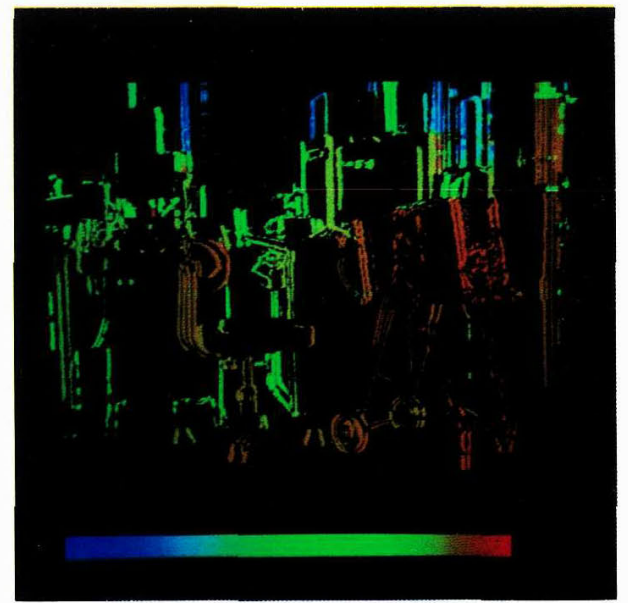

Fig. 9 The result for whole inage, considering the consistency across scanlines 
西谷・船橋：ネットワーク算法による両眼立体視の対応点決定方法

ここに, $B R_{i}$ : 右眼像の各領域の平均明るさ $B L_{j}$ : 左眼像の各領域の平均明るさ

また，抵抗值更新のための重み係数ひは Fig. 6 に示 すようなガウス分布の Laplacian を，点線で示すよう な矩形で近似して用いている，乙の重み係数は収束の 速度に大きな影響を与える. Fig. 6 に示した係数は， 種々の画像に適用した結果最も良好であったものを示 した.この重み係数之収束速度については, 詳細な検 討を行い，別の機会に報告する. Fig. 5では微分值が 10.0 以上の部分に対する対応結果を表示し, それ以外 の部分はこれを補間している.

この対応点計算結果では, 98 番目の画素付近と, 398 番目の画素付近に誤った対応結果がある. 前者は. occluding すなわち左眼像にあるエッジが右眼像にな いために生じたあのである，つまり，Fig. 4の右眼像 のエッジ(イ)は，正しくは左眼像のエッジ(ロ)に対応 するあのであるが, 誤ってエッジ(八)に対応したあの である. 後者は右眼像の弱いエッジが左眼像の強いエ ッジに対応してしまった結果である.つまり，Fig. 4 の右眼像の弱いエッジ(二)は正しくは左眼像の(ホ)の 部分に対応すべきであるが，周囲の強いエッジ(へ)に 対応してしまったあのである. てれは，側抑制の重み づけパターンの, 興奮性の方向への幅が 3 画素と小さ いために, continuity が崩れたものと考えられる.

てのようにして, 各走査線毎に独立な対応点の探索 を全走査線に施し，三角測量の原理から奥行き距離を 求めた結果を Fig. 7 に示す. ここで, 奥行きの計算 結果は, 右眼像において微分值が 10.0 以上の画素に 対してのみ表示し, 近くの物体を赤とし, 遠方に遠ざ かるに従い青となるように表わしている. 先に述べた ような原因による誤った結果が多少あるが概ね正しい 結果が得られている. しかし，ての例では走査線毎に 独立な計算を行っているために, 数個の走査線では誤 った結果が非常に多くなっている. 次節において, こ の誤った対応結果を減少させるために, 走査線間の整 合性を考慮する方法について述べる.

\section{2 走査線間の整合性}

前節で述べた誤った対応部分を減少させるために走 查線間の整合性も考慮する方法を Fig. 8 亿示す. $s$ ラインにおいて対応点決定を行っているとき, $p^{s}$ 点 における抵抗值の更新は, $s$ ライン上の $p^{s}$ 点近傍の 点から側抑制をうけるばかりでなく, $(s+1)$ および $(s-1)$ ライン上の点 $p^{s+1}$ および $p^{s-1}$ 近傍の点から あ側抑制を受けるようにする. すなわち，抵抗值更新 を行う（4)式に扣いて, sライン上の回路網の抵抗 $R_{i j}$ を,

$$
R_{i j}^{t+1}=R_{i j}^{t}-\beta \sum_{p=s-1}^{s+1} \sum_{k, l} w(k, l) \cdot x_{k, l}^{p}
$$

より求める. ことに $x_{k, l}^{p}$ はpライン上の回路網での 電流值を示す.

これにより, 走査線方向と直交した方向にあ continuity を満足させるようにすることができる．この 走査線間の整合性も考慮に入れた計算結果を Fig. 9 に示す.

Fig. 7 と Fig. 9 を比較すると, Fig. 7 において悞 った対応決定をしていた走査線が減少し，走査線間の 整合性あ考慮した効果があらわれている.

\section{3 計算時間と精度の検討}

本章での計算例に要した cpu 時間は，大型汎用コン ピュータ $\mathrm{M}-200 \mathrm{H}$ を用いて, 走査線毎に独立な計算 で約 20 分，走査線間の整合性を考慮した計算で約 40 分である.との結果は, 移動ロボットの視覚としては まだ十分な速度とはいえず，今後ての高速化方式を検 討する必要がある.

前節までに示した計算例には，部分的に誤った対応 結果ああるが，正しい対応の部分では対応誤差は士 0.5 画素以内である. これは, $3 \mathrm{~m}$ の奥行き距離にあ る物体に対し， $\pm 6 \mathrm{~cm}$ の距離精度を得られるととを示 しており，乙の程度の誤差であれば，移動ロボットの 誘導には十分使用できると思われる.

\section{4. あとがき}

本論文では，ネットワーク算法を用いてステレオ対 応点を求める手法を明らかにした，すなわち，両眼視 像に対する対応点決定の方法として, 数理計画手法の ネットワーク計画法に, 生体系の基本的な視覚情報処 理様式である側抑制の考え方を導入した．画像内の各 画素から，対となる画像の対応画素付近に枝を張った ネットワーク (電気回路網) を構成する. 対となる画 像は非常に近似していることから, 対応点決定の問題 は, 一方の画像の特徵量を他方の画像へと, とのネッ トワークを通して輸送する場合の流れを求めるてとに なる. てのとき, 対応点決定のための拘束条件を満足 させるために，各枝に対するコスト（抵抗值）を側抑 制の考え方に基づき更新しながら，繰返し計算により 求める. 実画像による検討の結果, $3 \mathrm{~m}$ の距離にある 物体に対し $\pm 6 \mathrm{~cm}$ 程度の精度で距離が求まるととを 明らかにした。

最後に, 本研究の機会を与えてくださった, 当所川 崎淳所長, 井原廣一副所長, 春名公一部長, 本研究を 進めるにあたって有益な御意見, 御討論をいただいた 東北大学木村正行教授, また本研究の遂行にあたり御 
協力をいただいた各位に対し，ここに感謝の意を表し ます。

\section{参 考 文 献}

1) 藤江, 他: 知能移動ロボットのシステム構成, 第 2 回日 本ロボット学会学術講演会予稿集, 221/224 (1984)

2) 白井: ロボットの物体認識技術, 計測 と制御, 21-12, 1115/1121 (1982)

3) D. Marr and T. Poggio: Cooperative Computation of Stereo Disparity, Science, Vol. 194, 15 October 1976, 283/287 (1976)

4) 太田, 金出: 走査線間の整合性を考虑した動的計画法に よるステレオ対応探索, 情報処理学会コンピュータビジ ヨン研究会資料, 29-7 (1984)

5) H. P. Moravec: The Stanford Cart and The CMU
Rover, Proc. of The IEEE, 71-7, 872/884 (1983)

6) 谷内田: 多重画像を利用したシーンの理解, 情報処理, 24-12, 1429/1436 (1983)

7) D. Marr: Vision, W. H. Freeman and Company (1982)

8) T. ポッジオ：人間の視覚と機械の視覚, サインス日本版, 84-6 (1984)

9) 甘利：神経回路網の数理, 産業図書 (1978)

10) W. E. L. Grimson: From Images to Surfaces, MIT Press (1981)

11) M. Iri: Network Flow Transportation and Scheduling: Theory and Algorithms, Academic Press (1969)

12) L. R. Ford, Jr. and D. R. Fulkerson: Flows in Networks, Princeton University Press (1962) 